\title{
Thio-barbiturate-derived compounds are novel antioxidants to prevent LPS-induced inflammation in the liver
}

\author{
Kyoung Mi Moon ${ }^{1,5, *}$, Bonggi Lee ${ }^{1,5, *}$, Ji Won Jeong ${ }^{1}$, Dae Hyun Kim ${ }^{1}$, Yun Jung \\ Park $^{2}$, Hye Rim Kim², Ji Young Park², Min Jo Kim${ }^{1}$, Hye Jin An ${ }^{1}$, Eun Kyeong Lee ${ }^{1}$, \\ Young Mi $\mathrm{Ha}^{3}$, Eunok Im${ }^{1}$, Pusoon Chun ${ }^{4}$, Jin Yeul Ma ${ }^{5}$, Won-Kyung Cho ${ }^{5}$, Hyung \\ Ryong Moon ${ }^{2}$ and Hae Young Chung ${ }^{1}$ \\ ${ }^{1}$ Molecular Inflammation Research Center for Aging Intervention, College of Pharmacy, Pusan National University, Busan, \\ Korea \\ ${ }^{2}$ Laboratory of Medicinal Chemistry, College of Pharmacy, Pusan National University, Busan, Republic of Korea \\ ${ }^{3}$ Department of Chemistry, Dong-A University, Busan, Republic of Korea \\ ${ }^{4}$ College of Pharmacy, Inje University, Inje-ro, Gyeongnam, Korea \\ ${ }^{5}$ Korean Medicine-Application Center, Korea Institute of Oriental Medicine, Daegu, Republic of Korea \\ *These authors have contributed equally to this work \\ Correspondence to: Hae Young Chung, email: hyjung@pusan.ac.kr
}

Hyung Ryong Moon, email: mhr108@pusan.ac.kr

Keywords: oxidative stress, antioxidant, compound 2d, compound 2l, inflammation

Received: May 24, $2017 \quad$ Accepted: July 12, $2017 \quad$ Published: October 10, 2017

Copyright: Moon et al. This is an open-access article distributed under the terms of the Creative Commons Attribution License 3.0 (CC BY 3.0), which permits unrestricted use, distribution, and reproduction in any medium, provided the original author and source are credited.

\section{ABSTRACT}

Liver inflammation is closely associated with metabolic syndrome. Oxidative stress plays a synergistic role in inflammation by activating nuclear factor kappa $B(N F-K B)$ signaling in the liver. Therefore, substantial efforts have been made to develop compounds that inhibit the generation of oxidative stress and activation of NF-kB. We synthesized twenty-six novel 5-(substituted benzyl)-2-oxo- and 5-(substituted benzyl)-2-thioxo-dihydropyrimidine-4,6 $(1 \mathrm{H}, 5 \mathrm{H})$-dione derivatives for the development of potential antioxidants and examined their biological activities in vitro and in vivo. Thio-barbiturate-derived compounds 5-[4-hydroxy-3methoxybenzy]-2-thioxodihydropyrimidine-4,6[1H,5H]-dione (2d) and 5-[4-hydroxy3,5-methoxybenzy]-2-thioxodihydropyrimidine-4,6[1H,5H]-dione (2I) had the strongest inhibitory effect on reactive oxygen species and peroxynitrite generation in vitro. Furthermore, oral administration of compounds $2 \mathrm{~d}$ and $2 \mathrm{l}$ in mice notably suppressed lipopolysaccharide (LPS)-induced oxidative stress and NF-KB activation in the liver. Because macrophages play an essential role in liver inflammation, we investigated the effects of these compounds on inflammatory signaling in LPS-induced RAW264.7 macrophages. LPS-induced NF-KB activation and protein expression of cyclooxygenase 2 and inducible nitric oxide synthase were inhibited by pretreatment of these compounds in macrophages. In parallel with this finding, the phosphatase and tensin homolog deleted on chromosome 10 (PTEN) and AKT signalings, which are upstream activators of p65, were decreased by these compounds in macrophages. Our study suggests that compounds $2 \mathrm{~d}$ and $2 \mathrm{l}$ inhibit oxidative stress and NF-KBmediated inflammation, at least partially, through suppressing PTEN/AKT signaling. Therefore, these compounds may be useful as therapeutic agents for the amelioration of inflammatory diseases. 


\section{INTRODUCTION}

Lipopolysaccharide (LPS) induces secretion of proinflammatory cytokines by activating macrophages, which play a causal role in acute and chronic inflammation [1]. As liver inflammation is closely associated with hepatic cirrhosis, liver lesion, hepatic fibrosis, and liver cancer, treatment of inflammation is an important strategy for decreasing them [2-4]. Macrophages are a major immune cell population in the liver and play an essential role in liver inflammation-related diseases [1,5]. Macrophages can be activated in response to various inflammatory stimuli, including LPS [6-8].

The phosphatase and tensin homolog deleted on chromosome 10 (PTEN) is a widely expressed protein phosphatase [9]. Since various studies have reported that PTEN is frequently mutated or deleted in a variety of human cancers, PTEN has been considered as a tumor suppressor gene $[9,10]$. In addition, PTEN is associated with reactive oxygen species (ROS)mediated inflammatory signaling [11]. ROS increases autophosphorylation of PTEN and thereby inhibits its phosphates activity. As a result, activated AKT stimulates nuclear factor kappa B (NF- $\mathrm{kB})$-mediated inflammation [12].

Basally, inactive NF- $\mathrm{KB}$ is localized to the cytoplasm after forming a complex with an inhibitor of kappa B

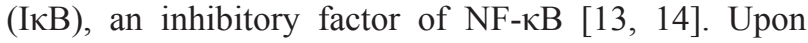
stimulation, activated AKT phosphorylates and activates inhibitor of kappa B kinase (IKK), which phosphorylates IאB [15]. Then, phosphorylated I $\mathrm{B}$ is dissociated from $\mathrm{NF}-\kappa \mathrm{B}$, and activated NF- $\mathrm{KB}$ is translocated to the nucleus, where it interacts with specific DNA binding sites to induce inflammatory gene transcription including, inducible nitric oxide synthase and cyclooxygenase 2 $[16,17]$.

Because there is a close relationship between oxidative stress and inflammation, we synthesized novel compounds with antioxidant activity. Of these compounds, we screened 5-[4-hydroxy-3methoxybenzy $]$-2-thioxodihydropyrimidine- $4,6[1 \mathrm{H}, 5 \mathrm{H}]$ dione (2d) and 5-[4-hydroxy-3,5-methoxybenzy]-2thioxodihydropyrimidine-4,6[1H,5H]-dione (21) and further studied their anti-inflammatory properties and underlying mechanisms using $\mathrm{C} 57 \mathrm{BL} / 6$ mice and RAW264.7 macrophages after LPS treatment.

\section{RESULTS AND DISCUSSION}

\section{Screening of compounds $2 \mathrm{~d}$ and $2 \mathrm{I}$ as ROS and ONOO- scavengers}

Reactive oxygen species (ROS) and peroxynitrite $\left(\mathrm{ONOO}^{-}\right)$play a critical role in liver inflammation by regulating the expression of pro-inflammatory cytokines [18]. We examined the effects of 26 5-(substituted benzyl)-2-oxo- and 5-(substituted benzyl)-2-thioxodihydropyrimidine-4,6(1H,5H)-dione derivatives (Table 1) on ROS and $\mathrm{ONOO}^{-}$production in vitro after 3-morpholinosydnonimine (SIN-1) stimulation. The well-known ROS inhibitor trolox and the ONOOinhibitor penicillamine were used as positive controls (Figure 1C-1D). Of these derivatives, compounds $2 \mathrm{~d}$ and 21 were screened further because their ROS and $\mathrm{ONOO}^{-}$scavenging activities were greater than those of the positive controls (Figure 2A-2B). We examined the dose-dependent effects of these compounds on ROS and $\mathrm{ONOO}^{-}$scavenging activity and found that compounds $2 \mathrm{~d}$ and 21 dose- dependently inhibited SIN-1-induced ROS and $\mathrm{ONOO}^{-}$generation in vitro (Figure 2A-2B), suggesting that these compounds inhibit SIN-1-mediatied oxidative stress.

\section{Inhibitory effects of compounds $2 \mathrm{~d}$ and $2 \mathrm{l}$ on oxidative stress and NF- $\mathrm{KB}$ signaling in the liver}

To investigate whether compounds $2 \mathrm{~d}$ and 21 affect antioxidant and anti-inflammatory signaling in the liver, each compound $2 \mathrm{~d}$ and $21(0.2 \mu \mathrm{M}$ and $1 \mu \mathrm{M})$ was delivered to $\mathrm{C} 57 \mathrm{BL} / 6$ mice by oral gavage prior to an intraperitoneal injection of lipopolysaccharide (LPS) (5 $\mathrm{mg} / \mathrm{kg}$ ). We examined oxidative stress and its downstream nuclear factor kappa B (NF-KB) activity. ONOO- levels were significantly increased in the LPS-injected group compared to the non-injected group, but pretreatment with compounds $2 \mathrm{~d}$ and 21 dose-dependently inhibited LPSinduced increases in ROS and ONOO- levels in the liver (Figure 3A-3B), indicating that these compounds inhibited LPS-induced oxidative stress. Because oxidative stress is closely associated with LPS-induced activation of NF- $\mathrm{KB}$ signaling, we studied whether the compounds affect NF- $\mathrm{kB}$ protein expression and activity. Compounds $2 \mathrm{~d}$ and 21 at $1 \mu \mathrm{M}$ significantly decreased protein levels of p65 and phosphorylated p65 (Ser536) in the nucleus of the liver (Figure 3C), indicating that the compounds inhibited NF$\kappa \mathrm{B}$ signaling. Considering the close relationship between oxidative stress and NF- $\kappa B$ activation, compound $2 \mathrm{~d}$ and compound 21-mediated inhibition of NF- $\kappa \mathrm{B}$ may be associated with the suppression of oxidative stress.

\section{Inhibitory effects of compounds $2 \mathrm{~d}$ and 21 on LPS-induced oxidative stress in macrophages}

Macrophages play an essential role in regulating inflammation in the liver, especially after LPS stimulation [19-21]. We used an RAW264.7 macrophage cell line to investigate the effect of compounds $2 \mathrm{~d}$ and 21 on LPSinduced oxidative signaling. We confirmed that compounds $2 \mathrm{~d}$ or 21 were not cytotoxic at the concentration up to $50 \mu \mathrm{M}$ (Figure 4A). Oxidative stress has been shown to activate macrophages [22]. We investigated whether compounds $2 \mathrm{~d}$ and $2 \mathrm{l}$ exhibited ROS and $\mathrm{ONOO}^{-}$scavenging activity 
in macrophages. LPS markedly elevated cellular levels of ROS and $\mathrm{ONOO}^{-}$but the compounds dose-dependently lowered these levels in macrophages (Figure 4B-4C). In addition, visual observation of ROS and $\mathrm{ONOO}^{-}$production using fluorescent microscopy showed that compounds $2 \mathrm{~d}$ and 21 notably reduced ROS and $\mathrm{ONOO}^{-}$generation (Figure 4D-4E), confirming that these compounds suppress LPSinduced oxidative stress in macrophages.

A<smiles>COc1cc(CC2C(=O)NC(=S)NC2=O)ccc1O</smiles>

2d

B<smiles>COc1cc(CC2C(=O)NC(=S)NC2=O)cc(OC)c1O</smiles>

2I

C

ROS

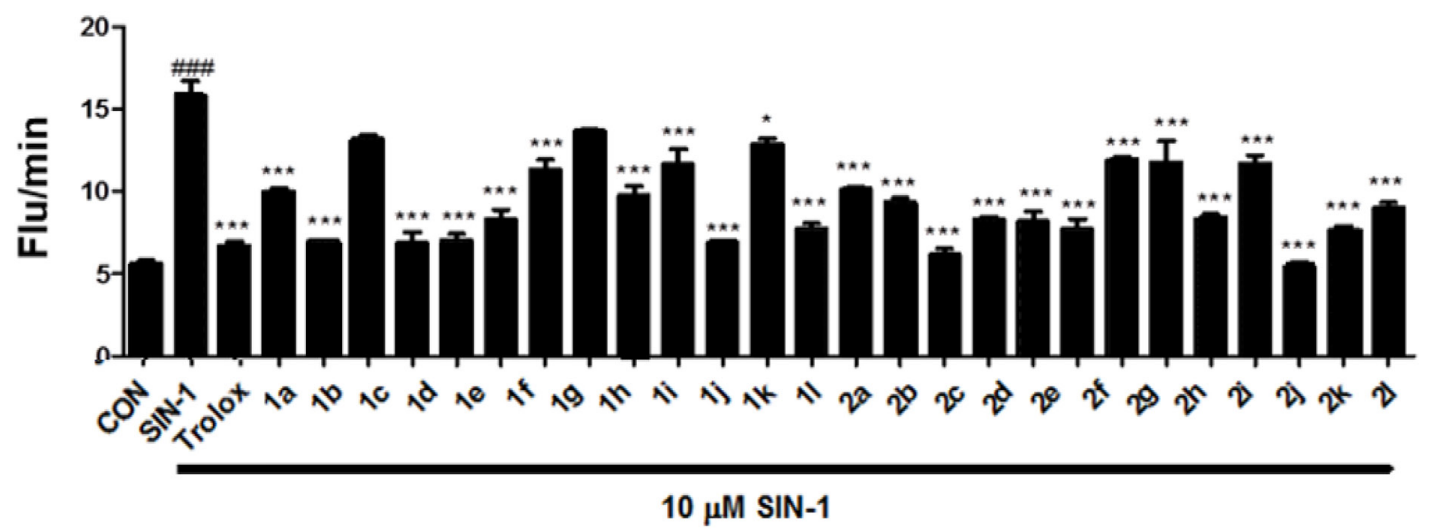

D

ONOO-

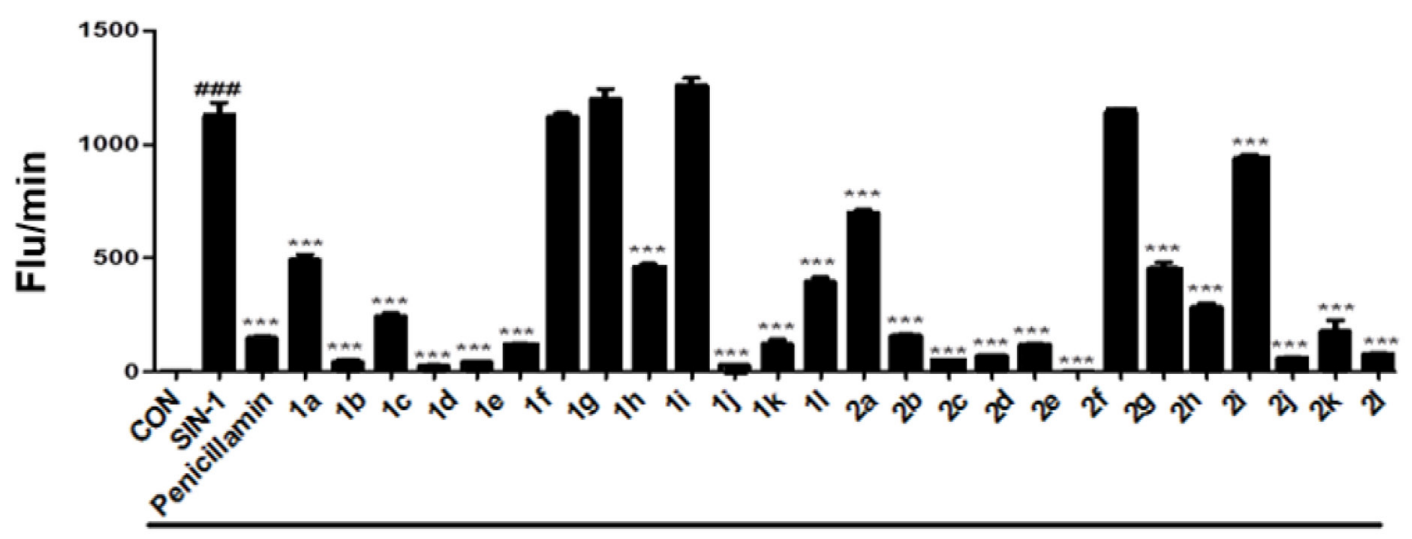

$10 \mu \mathrm{M} \mathrm{SIN-1}$

Figure 1: Screening of thio-barbiturate-derived compounds. (A) The structures of 5-[4-hydroxy-3-methoxybenzy]-2thioxodihydropyrimidine-4,6[1H,5H]-dione (2d) and (B) 5-[4-hydroxy-3,5-methoxybenzy]-2-thioxodihydropyrimidine-4,6[1 H,5H]-dione (21). (C) Reactive oxygen species (ROS) and (D) peroxynitrite (ONOO-) were measured in vitro using DCFDA and DHR123, respectively. The data are shown as the mean \pm SEM $(n=3)$. Statistical results of one-way ANOVA, followed by the Dunnett's test: \#\#\# $<0.001$ vs. a control group, ${ }^{*} p<0.05,{ }^{* * *} p<0.001$ vs. the 3-morpholinosydnonimine (SIN-1)-treated group. 
Effects of compounds 2d and 2l on LPS-induced $\mathrm{NF}-\kappa \mathrm{B}$ signaling in macrophages

The activation of NF- $\mathrm{KB}$ signaling is key characteristics of macrophage activation [17]. We examined effects of the compounds on NF- $\mathrm{KB}$ activity in macrophages. Western blot analysis showed that phosphorylation of NF- $\mathrm{KB}$ at Ser536, was dosedependently decreased by compounds $2 \mathrm{~d}$ and 21 in macrophages (Figure 5A). It is known that the NF$\kappa \mathrm{B}$ can be activated through phosphorylation of p65 at Ser536, which is regulated through the toll-like

A

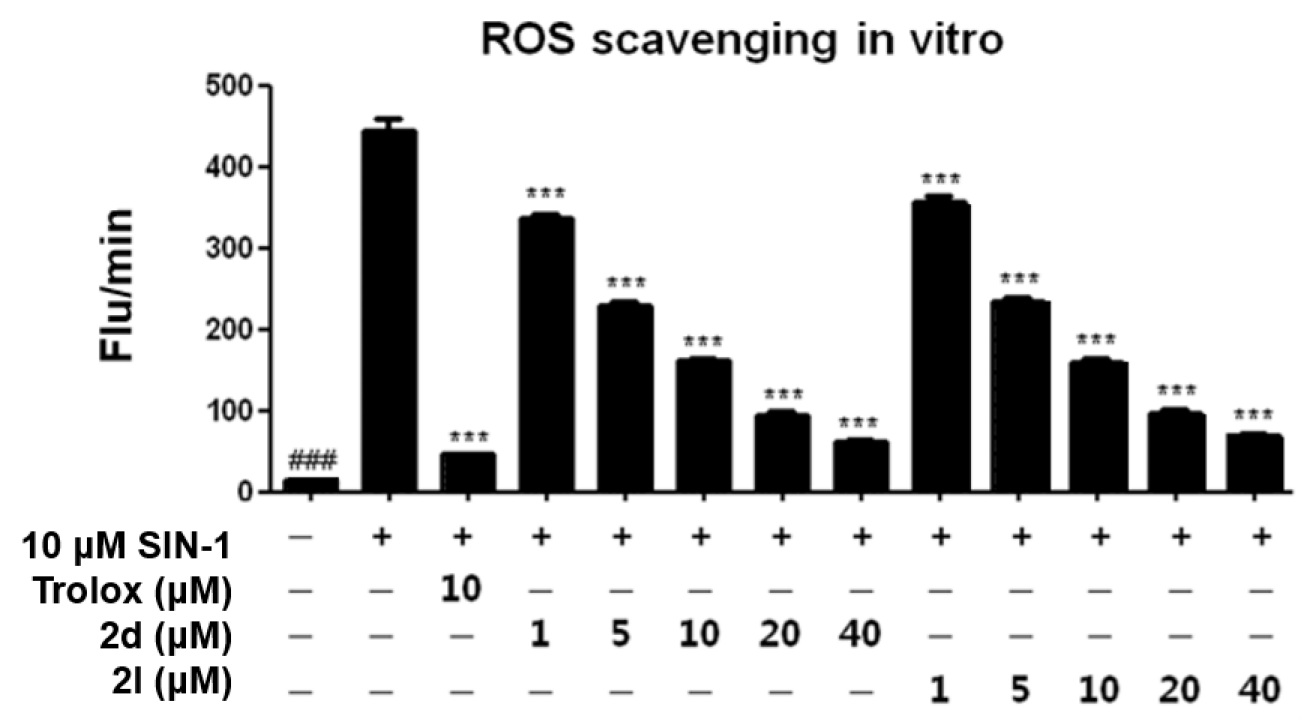

B

Figure 2: Effects of compound 2d or compound 21 treatment on ROS and ONOO- scavenging in vitro. (A) ROS and (B) $\mathrm{ONOO}^{-}$were measured in vitro using DCFDA and DHR123, respectively. Trolox and penicillamine were used as a known ROS and ONOOinhibitor, respectively. The data are shown as the mean \pm SEM $(n=5)$. Statistical results of one-way ANOVA, followed by the Dunnett's test: $\# \#$ \# $<0.001$ vs. a control group, ${ }^{* * *} p<0.001$ vs. a SIN-1-treated group. 


\begin{tabular}{|c|c|c|c|c|c|}
\hline Compounds & $\mathbf{X}$ & $\mathbf{R}^{1}$ & $\mathbf{R}^{2}$ & $\mathbf{R}^{3}$ & $\mathbf{R}^{4}$ \\
\hline $1 \mathrm{a}$ & $\mathrm{O}$ & $\mathrm{H}$ & $\mathrm{H}$ & $\mathrm{OH}$ & $\mathrm{H}$ \\
\hline $1 b$ & $\mathrm{O}$ & $\mathrm{H}$ & $\mathrm{OH}$ & $\mathrm{OH}$ & $\mathrm{H}$ \\
\hline $1 \mathrm{c}$ & $\mathrm{O}$ & $\mathrm{OH}$ & $\mathrm{H}$ & $\mathrm{OH}$ & $\mathrm{H}$ \\
\hline $1 d$ & $\mathrm{O}$ & $\mathrm{H}$ & $\mathrm{OMe}$ & $\mathrm{OH}$ & $\mathrm{H}$ \\
\hline $1 \mathrm{e}$ & $\mathrm{O}$ & $\mathrm{H}$ & OEt & $\mathrm{OH}$ & $\mathrm{H}$ \\
\hline $1 f$ & $\mathrm{O}$ & $\mathrm{H}$ & $\mathrm{OH}$ & $\mathrm{OMe}$ & $\mathrm{H}$ \\
\hline $1 \mathrm{~g}$ & $\mathrm{O}$ & $\mathrm{H}$ & $\mathrm{H}$ & $\mathrm{OMe}$ & $\mathrm{H}$ \\
\hline $1 \mathrm{~h}$ & $\mathrm{O}$ & $\mathrm{H}$ & $\mathrm{OMe}$ & $\mathrm{OMe}$ & $\mathrm{H}$ \\
\hline 1i & $\mathrm{O}$ & $\mathrm{OMe}$ & $\mathrm{H}$ & $\mathrm{OMe}$ & $\mathrm{H}$ \\
\hline $1 \mathrm{j}$ & $\mathrm{O}$ & $\mathrm{H}$ & $\mathrm{OMe}$ & $\mathrm{OMe}$ & $\mathrm{OMe}$ \\
\hline $1 \mathrm{k}$ & $\mathrm{O}$ & $\mathrm{H}$ & $\mathrm{OMe}$ & $\mathrm{OH}$ & $\mathrm{OMe}$ \\
\hline 11 & $\mathrm{O}$ & $\mathrm{H}$ & $\mathrm{Br}$ & $\mathrm{OH}$ & $\mathrm{Br}$ \\
\hline $2 a$ & $\mathrm{~S}$ & $\mathrm{H}$ & $\mathrm{H}$ & $\mathrm{OH}$ & $\mathrm{H}$ \\
\hline $2 b$ & $\mathrm{~S}$ & $\mathrm{H}$ & $\mathrm{OH}$ & $\mathrm{OH}$ & $\mathrm{H}$ \\
\hline $2 \mathrm{c}$ & $\mathrm{S}$ & $\mathrm{OH}$ & $\mathrm{H}$ & $\mathrm{OH}$ & $\mathrm{H}$ \\
\hline $2 \mathrm{~d}$ & $\mathrm{~S}$ & $\mathrm{H}$ & $\mathrm{OMe}$ & $\mathrm{OH}$ & $\mathrm{H}$ \\
\hline $2 \mathrm{e}$ & $\mathrm{S}$ & $\mathrm{H}$ & OEt & $\mathrm{OH}$ & $\mathrm{H}$ \\
\hline $2 \mathrm{f}$ & $\mathrm{S}$ & $\mathrm{H}$ & $\mathrm{OH}$ & $\mathrm{OMe}$ & $\mathrm{H}$ \\
\hline $2 g$ & $\mathrm{~S}$ & $\mathrm{H}$ & $\mathrm{H}$ & $\mathrm{OMe}$ & $\mathrm{H}$ \\
\hline $2 \mathrm{~h}$ & $\mathrm{~S}$ & $\mathrm{H}$ & $\mathrm{OMe}$ & $\mathrm{OMe}$ & $\mathrm{H}$ \\
\hline $2 \mathrm{i}$ & $\mathrm{S}$ & $\mathrm{OMe}$ & $\mathrm{H}$ & $\mathrm{OMe}$ & $\mathrm{H}$ \\
\hline $2 \mathrm{j}$ & $\mathrm{S}$ & $\mathrm{OH}$ & $\mathrm{H}$ & $\mathrm{H}$ & $\mathrm{H}$ \\
\hline $2 \mathrm{k}$ & $\mathrm{S}$ & $\mathrm{H}$ & $\mathrm{OMe}$ & $\mathrm{OMe}$ & $\mathrm{OMe}$ \\
\hline 21 & $\mathrm{~S}$ & $\mathrm{H}$ & $\mathrm{OMe}$ & $\mathrm{OH}$ & $\mathrm{OMe}$ \\
\hline $2 \mathrm{~m}$ & $\mathrm{~S}$ & $\mathrm{H}$ & $\mathrm{Br}$ & $\mathrm{OH}$ & $\mathrm{H}$ \\
\hline $2 n$ & $\mathrm{~S}$ & $\mathrm{H}$ & $\mathrm{Br}$ & $\mathrm{OH}$ & $\mathrm{Br}$ \\
\hline
\end{tabular}

receptor 4- phosphatidylinositol 3 kinase (PI3K)/ AKT pathway. We used immunohistochemistry to demonstrate that the compounds inhibited NF- $\mathrm{KB}$ translocation. LPS-induced nuclear translocation of $\mathrm{NF}-\kappa \mathrm{B} / \mathrm{p} 65$ was dose-dependently blocked by treatment with compounds $2 \mathrm{~d}$ and 21 (Figure 5B). To investigate 
the effect of the compounds on NF- $\kappa \mathrm{B}$ transcriptional activity, an NF- $\mathrm{B}$ luciferase assay was performed in macrophages. LPS treatment highly increased $\mathrm{NF}-\kappa \mathrm{B}$ transcriptional activity, whereas compounds $2 \mathrm{~d}$ and 21 significantly decreased it (Figure 5C). Likewise, protein levels of the inflammatory proteins inducible nitric oxide synthase and cyclooxygenase 2 , downstream targets of $\mathrm{NF}-\kappa \mathrm{B}$, were reduced by compounds $2 \mathrm{~d}$ and 21 (Figure 5D) in macrophages. These data clearly show that the compounds suppress $\mathrm{NF}-\kappa \mathrm{B}$ activation in macrophages.

\section{Compounds 2d and 21 inhibit PI3K/AKT signaling in RAW264.7 macrophages}

The phosphatase and tensin homolog deleted on chromosome 10 (PTEN) is an important phosphatase that inhibits the phosphorylation of NF- $\mathrm{kB}$ at Ser536 by the PI3K/ AKT pathway [23]. Because compounds $2 \mathrm{~d}$ and 21 inhibited NF- $\kappa$ B phosphorylation at Ser536, we determined by western blot whether these compounds regulated PTEN/AKT signaling. LPS treatment increased phosphorylation PTEN and AKT, but compounds $2 \mathrm{~d}$ and 21 reduced them (Figure 6A).

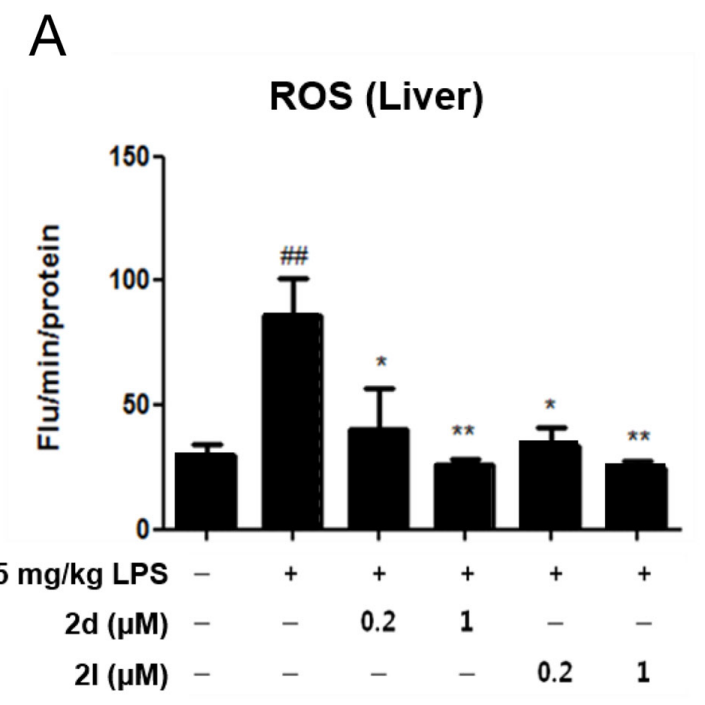

B
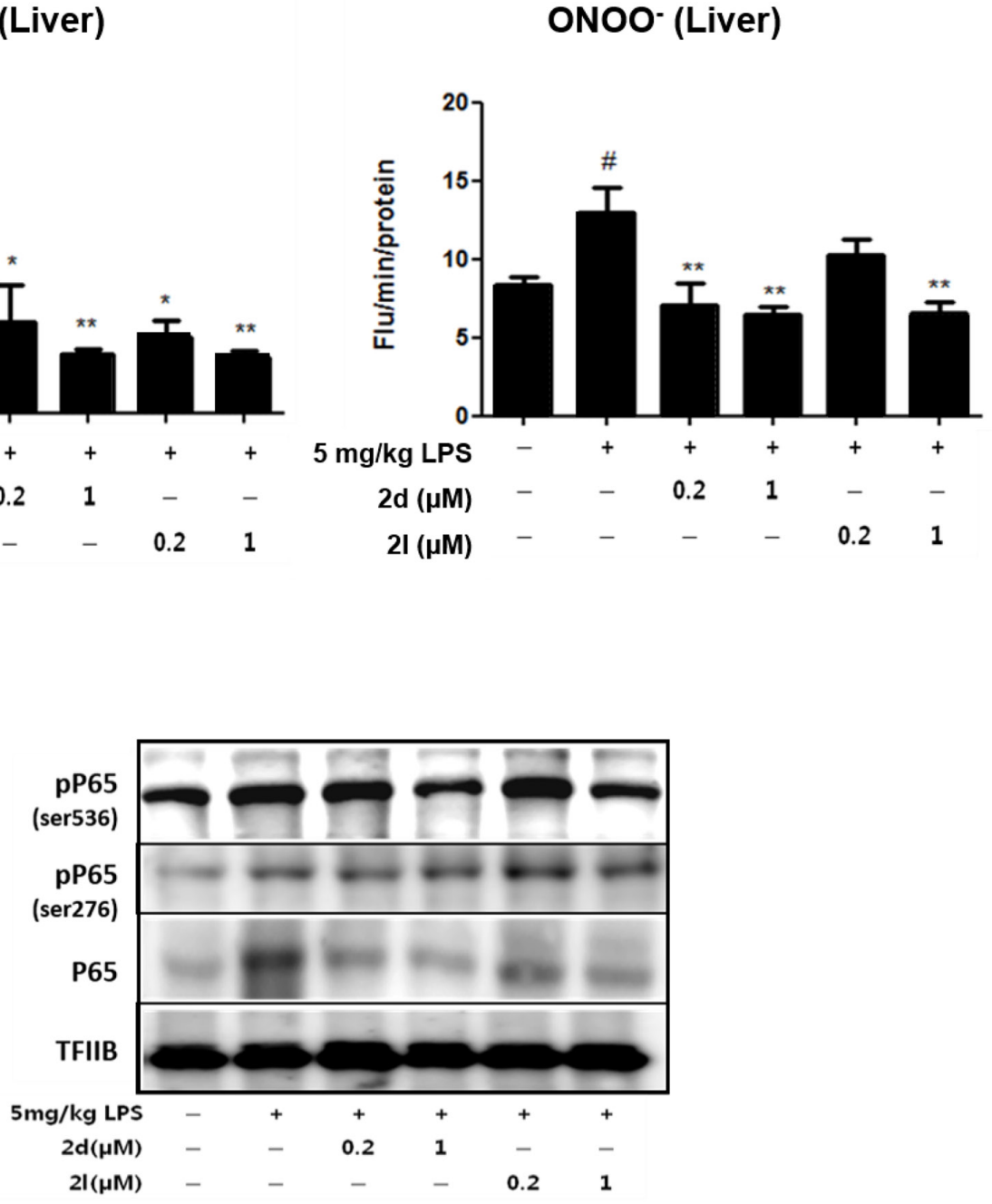

Figure 3: Compounds 2d and 21 ameliorate inflammation in lipopolysaccharide (LPS)-induced liver injury. Different concentrations of compounds $2 \mathrm{~d}$ and $21(0.2 \mu \mathrm{M}$ or $1 \mu \mathrm{M})$ were orally administered (PO) to C57BL/6 mice, and $2 \mathrm{~h}$ later, mice were treated with LPS $(5 \mathrm{mg} / \mathrm{kg})$. Mice were sacrificed $1 \mathrm{~h}$ after the LPS injection ( $\mathrm{n}=5 /$ group). Inhibitory effects of compounds $2 \mathrm{~d}$ and 21 on (A) ROS levels and (B) ONOO- levels. (C) Western blotting was performed to examine the effects of compounds $2 \mathrm{~d}$ and 21 on p-p65 (ser536), and p65 in the nucleus of the liver. Transcription Factor II B (TFIIB) was used as a loading control for the nucleus. The data are shown as the mean \pm SEM. Statistical results of one-way ANOVA followed by the Dunnett's test: $\# p<0.05$, \#\#p 0.01 vs. a control mice, ${ }^{*} p<0.05$, ${ }^{* *} p<0.01$ vs. LPS-treated mice. 
AKT phosphorylation activates NF- $\kappa$ B by phosphorylating inhibitor of kappa $\mathrm{B}$ kinase (IKK),

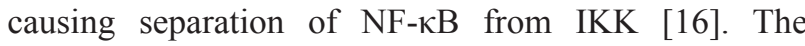
treatment of macrophages with LPS for $2 \mathrm{~h}$ increased phosphorylation of IKK $\alpha / \beta$ and inhibitor of kappa B (IкB) $\alpha$, whereas compounds $2 \mathrm{~d}$ and 21 inhibited it (Figure $6 \mathrm{~B}$ ). Based on these data, the $2 \mathrm{~d}$ - and 2l- mediated inhibition of NF- $\kappa \mathrm{B}$ activation is likely due to the suppression of PTEN/AKT signaling.

Our study focused on the compounds $2 \mathrm{~d}$ and 21 based on stronger ROS and $\mathrm{ONOO}^{-}$scavenging activities than other compounds. However, most of the 5-(substituted benzyl)-2-oxo- and 5-(substituted benzyl)-2-thioxo-dihydropyrimidine-4,6(1H,5H)-dione derivatives significantly decreased SIN-1-induced ROS and $\mathrm{ONOO}^{-}$production. Because the antioxidative effects of compounds $2 \mathrm{~d}$ and 21 are closely related to the decreased inflammatory signaling, other compounds may also ameliorate inflammation in the liver. Furthermore, it is necessary to examine structural mechanisms by which thio-barbiturate-derived compounds exhibit strong antioxidative activity.

The study showed that the compound $2 \mathrm{~d}-$ or 21 suppressed NF- $\mathrm{B}$ signaling in macrophages post
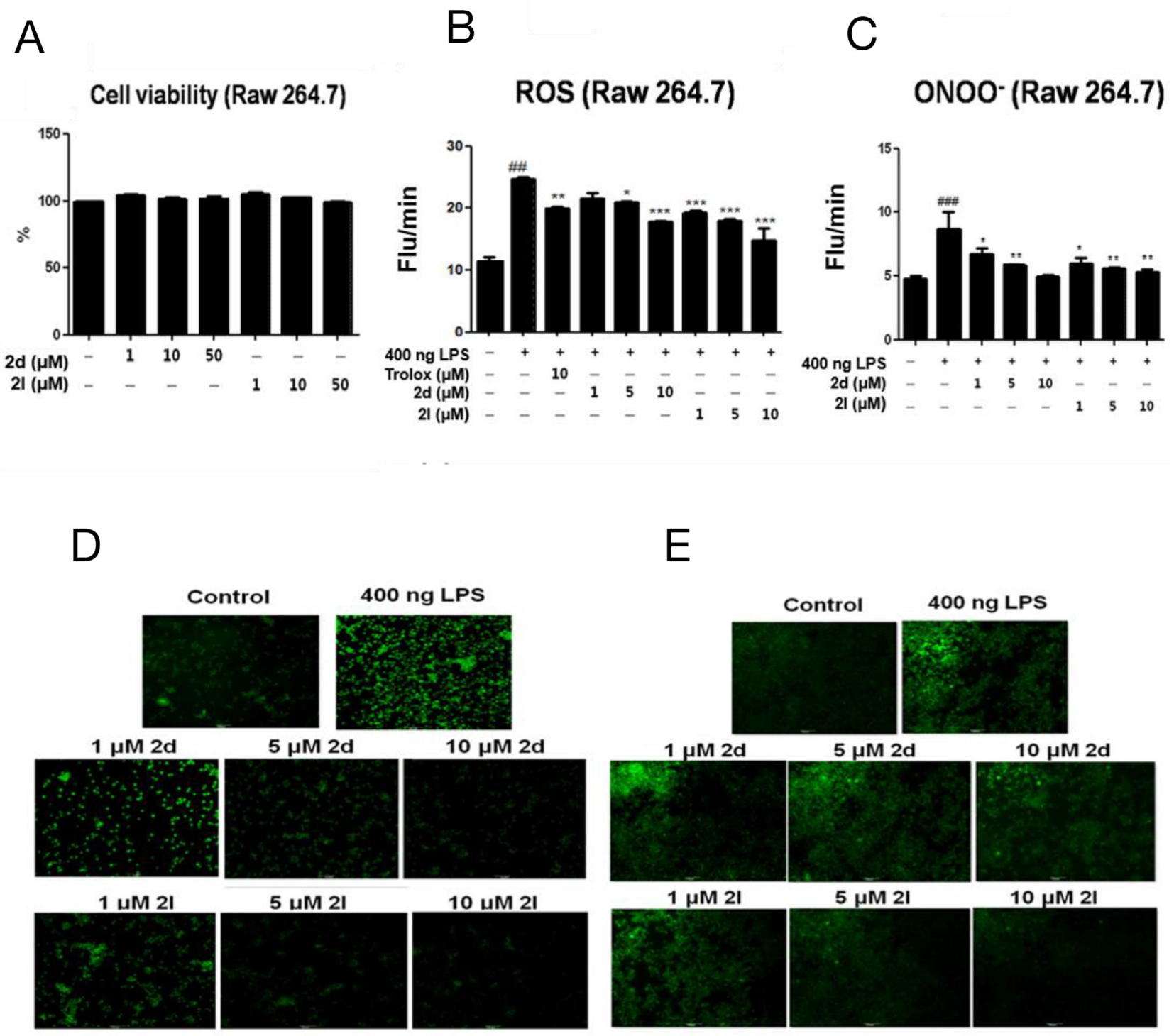

Figure 4: Inhibitory effects of compounds 2d and 21 on LPS-induced oxidative stress in macrophages. (A) Cell viability was examined inRAW264.7 cells treated with various doses of compounds $2 \mathrm{~d}$ or $21(1-50 \mu \mathrm{M})$. RAW264.7 cells were pretreated with compounds $2 \mathrm{~d}$ or $21(1-10 \mu \mathrm{M})$ for $1 \mathrm{~h}$, followed by 400ng LPS treatment for $18 \mathrm{~h}$. Suppression of intracellular (B) ROS and (C) ONOOlevels by compounds $2 \mathrm{~d}$ and 21 (1-10 $\mu \mathrm{M}$ ). Fluorescence microscopic images show intracellular (D) ROS and (E) ONOO- in RAW264.7 cells. Values represent the mean \pm SEM of three experiments. Data are expressed as \% of cell viability. Statistical results of one-way ANOVA followed by the Dunnett's test: \#\#p <0.01, \#\#\#p<0.001 vs. non-treatment, ${ }^{*} p<0.05,{ }^{* *} p<0.01,{ }^{* * *} p<0.001$ vs. LPS-treated cells 

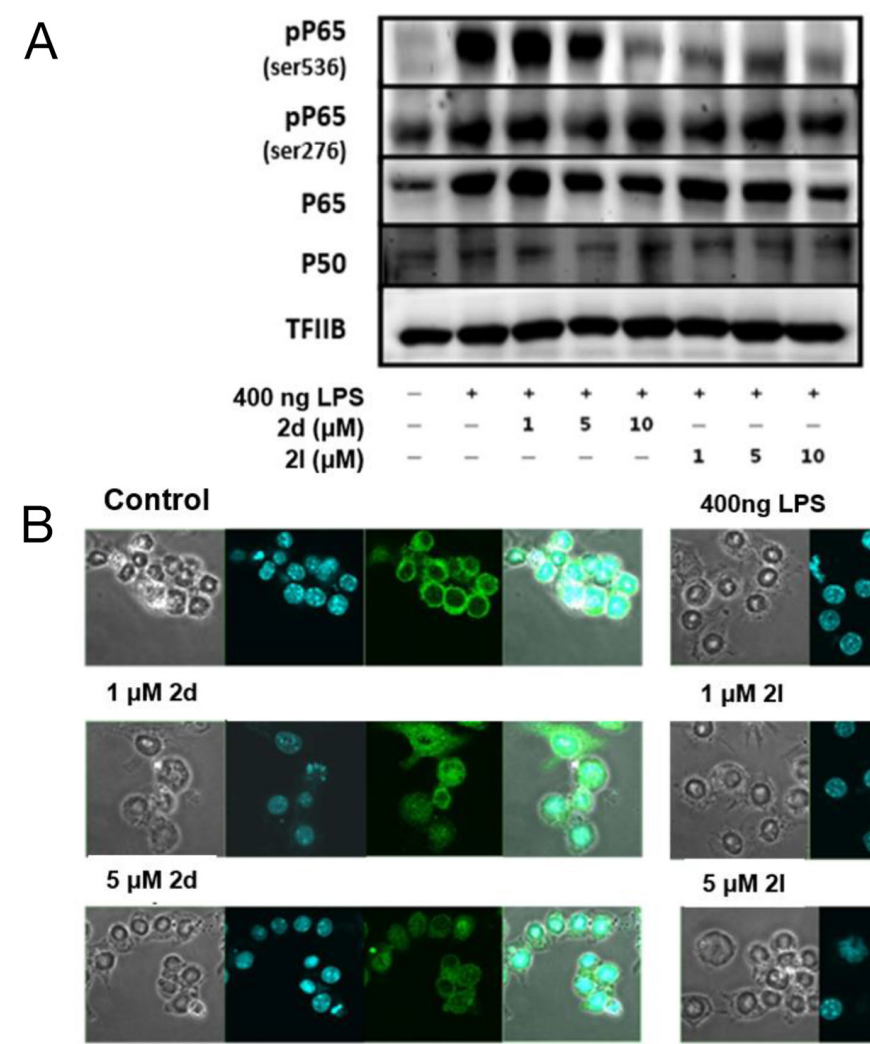

400ng LPS

\section{$10 \mu \mathrm{M} 2 \mathrm{~d}$}
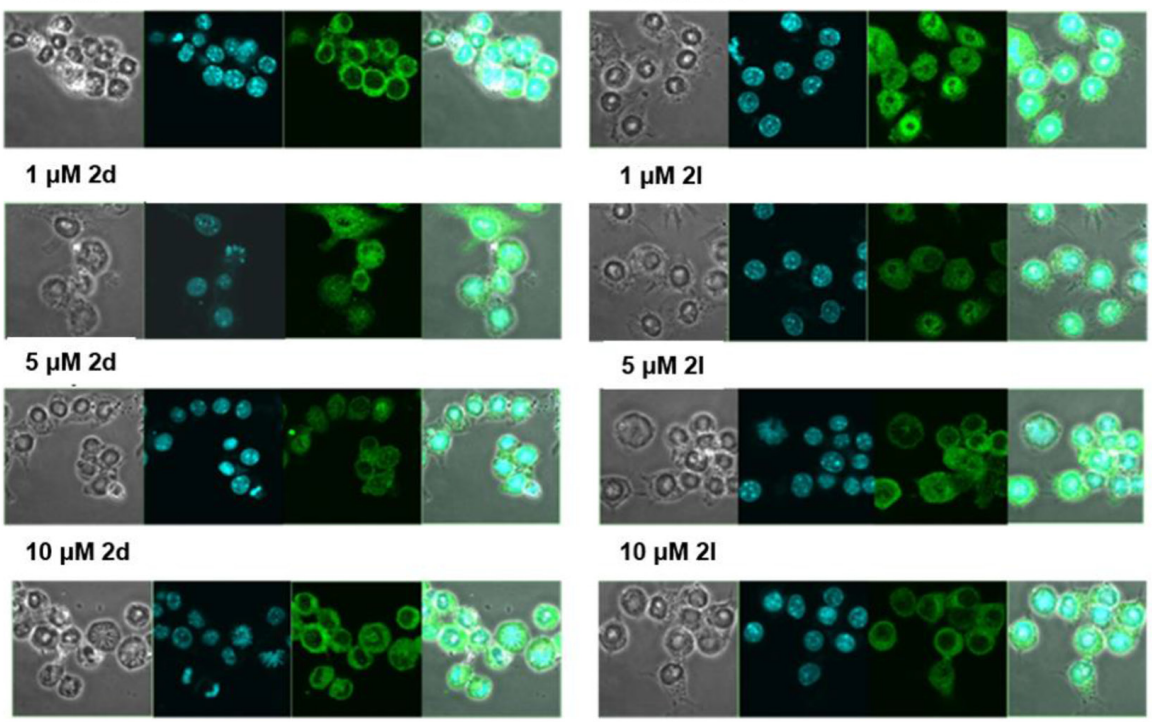

$1 \mu \mathrm{M} 2 \mathrm{I}$
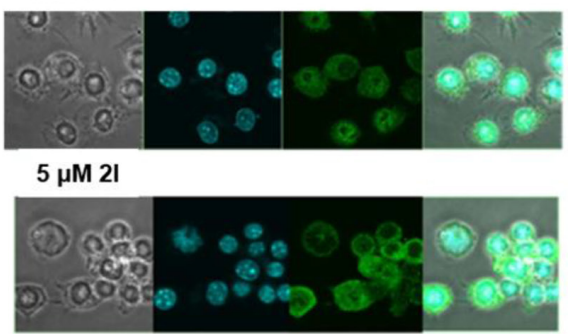

$10 \mu \mathrm{M} 2 \mathrm{I}$

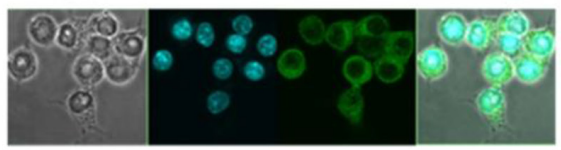

C

Luciferase assay (Raw264.7)
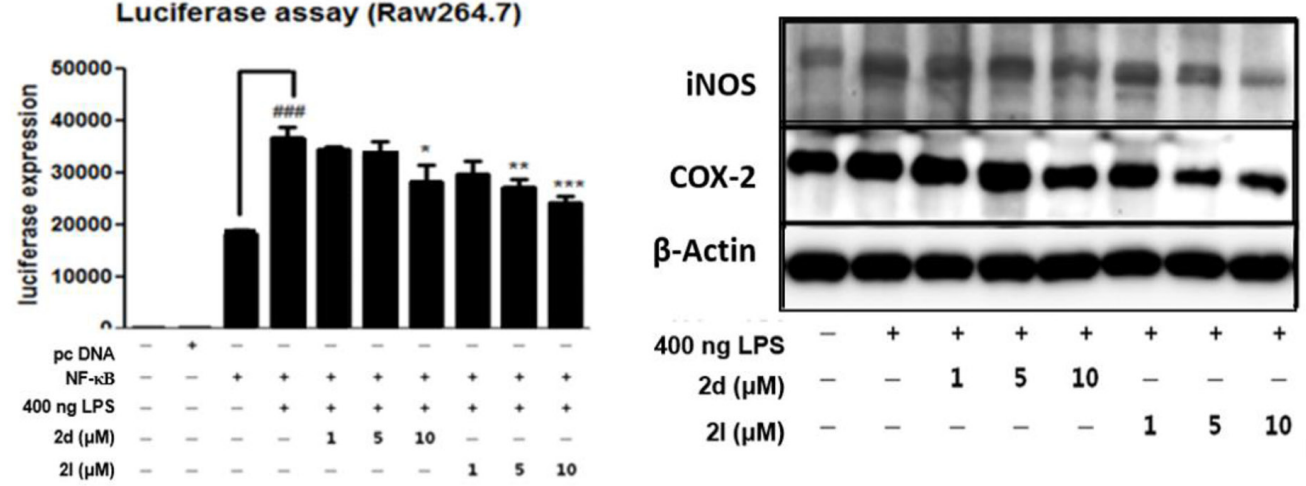

Figure 5: Inhibition of nuclear factor kappa B (NF-кB) activity by compounds 2d and 21. (A) RAW264.7 cells were pretreated with compounds $2 \mathrm{~d}$ or $2 \mathrm{l}(1-10 \mu \mathrm{M})$ for $1 \mathrm{~h}$, followed by $400 \mathrm{ng}$ LPS treatment for $2 \mathrm{~h}$. The cells were fractionated into cytosolic and nuclear portions and analyzed by western blot analysis. TFIIB was used as a marker of the nuclear fraction. (B) RAW264.7 cells were pretreated with the compound $2 \mathrm{~d}$ or compound $2 \mathrm{l}(1-10 \mu \mathrm{M})$ for $1 \mathrm{~h}$. After LPS (400ng) was treated for $2 \mathrm{~h}$ to induce NF- $\mathrm{kB}$ translocation, the cells were stained with an anti-p65 antibody (p65; Green) and Hoechst (nucleus; blue). p65-positive cells were counted and depicted by confocal fluorescence microscopy. The representative images were shown. (C) Both compounds $2 \mathrm{~d}$ and 21 inhibited the transcriptional activity of NF-kB based on a luciferase assay.The NF-kB luciferase reporter vectors were transfected in Raw264.7cells for $12 \mathrm{~h}$. Then, the cells were pretreated with compounds $2 \mathrm{~d}$ or $2 \mathrm{l}(1-10 \mu \mathrm{M})$ for $1 \mathrm{~h}$, followed by 400ng LPS treatment for $2 \mathrm{~h}$. (D) Western blotting was performed to examine the effects of compounds $2 \mathrm{~d}$ and 21 on cytosolic protein levels of inducible nitric oxide synthase and cyclooxygenase 2 in the liver. $\beta$-Actin was used as a loading control in the cytosolic fraction. tatistical results of one-way ANOVA followed by the Dunnett's

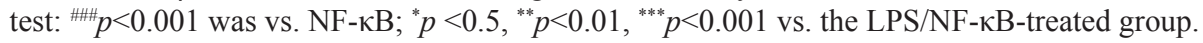


LPS treatment, but it may not be the only mechanism underlying the compound-mediated decrease in the liver inflammation. Because there are reports that other cell types in the liver including hepatocytes, lymphocytes, dendritic cell, and sinusoidal endothelial cells are also important mediators of inflammation [24]. Thus, it is likely that the anti-inflammatory effects of the compounds $2 \mathrm{~d}$ and $2 \mathrm{l}$ in the liver is not only caused by its effect on macrophages but also arise from its effect on other cell types.
In conclusion, compounds $2 \mathrm{~d}$ and 21 notably inhibited inflammation triggered by LPS, at least in part, by suppressing PTEN/AKT-mediated NF- $\kappa$ B activation in RAW264.7 cells. We speculate that the anti-inflammatory properties of the compounds are attributed to ROS and $\mathrm{ONOO}^{-}$scavenging activity. Consistently, when administrated orally, compounds $2 \mathrm{~d}$ and 21 effectively inhibited LPS-induced liver inflammation in vivo. Compounds $2 \mathrm{~d}$ and 21 may be promising pharmacological agents for the treatment of liver inflammatory disorders.

A

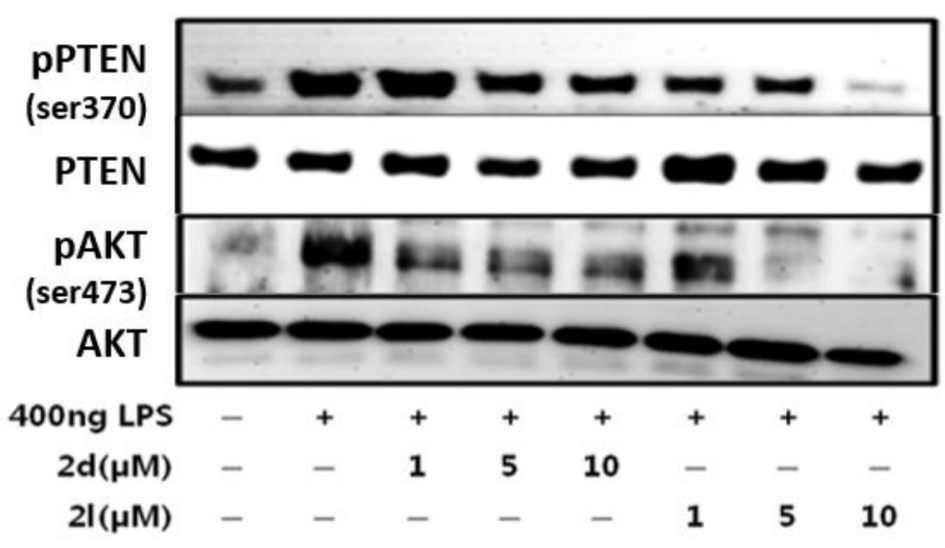

B

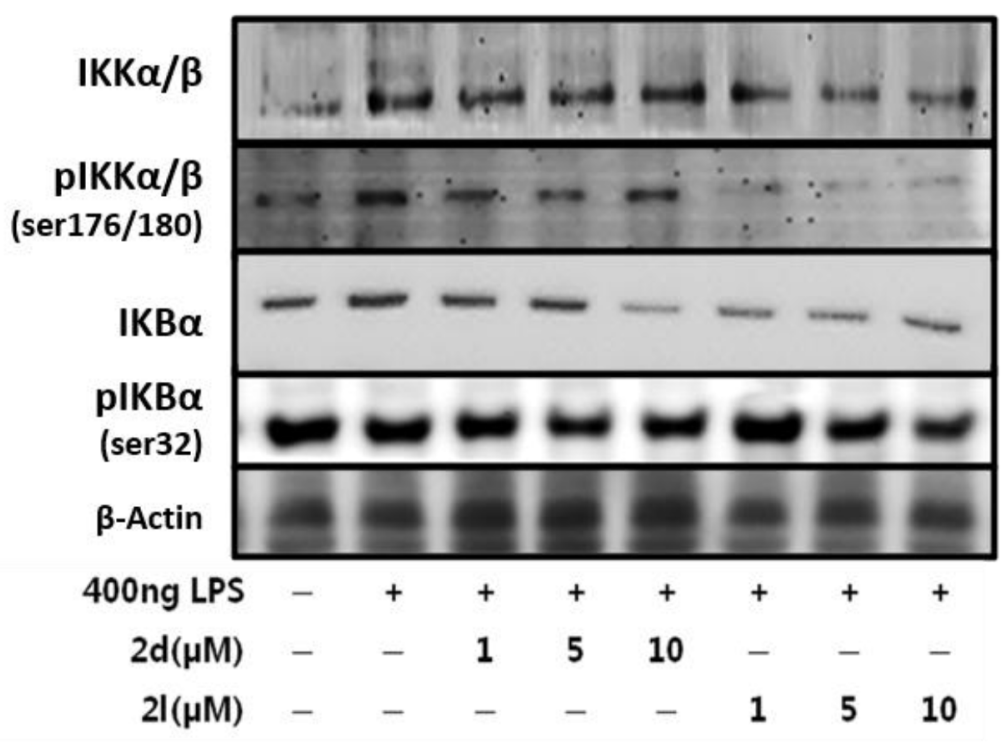

Figure 6: Effects of compounds $2 d$ and 21 on AKT/NF-KB signaling in LPS-stimulated RAW264. 7 cells. Western blotting was performed to detect protein levels of (A) PTEN and AKT, and (B) IKK $\alpha / \beta$ and IKb $\alpha$ in Raw264.7 cells. $\beta$-Actin was used as the loading control. 


\section{MATERIALS AND METHODS}

\section{Materials}

Compounds $2 \mathrm{~d}$ and 21 were synthesized in our laboratory. The condensation reaction of the thiobarbituric acid with vanillin (4-hydroxy-3methoxybenzaldehyde) and syringaldehyde (4-hydroxy3,5-dimethoxybenzaldehyde) in ethanol and water (1:1) afforded 5-(4-hydroxy-3-methoxybenzylidene) thiobarbituric acid and 5-(4-hydroxy-3,5dimethoxybenzylidene)thiobarbituric acid, respectively. After ethanol was added to the each product, $\mathrm{NaBH}_{4}$ (3.0 eq.) was added portion wise and stirred at room temperature to reduce carbon-carbon double bond of exomethylene of the thiobarbituric acid products. Volatiles were evaporated and water was added to the resulting residue. Precipitates generated after $\mathrm{pH}$ adjustment to 7 using $1 \mathrm{~N}-\mathrm{HCl}$ were filtered and washed with ether/water $(10-20: 1)$ and ethanol/ water $(10-20: 1)$ to give compounds $2 \mathrm{~d}$ and 21 , respectively. 5-(4-Hydroxy-3-methoxybenzyl)-2thioxodihydropyrimidine-4,6(1H,5H)-dione (compound 2d): ${ }^{1} \mathrm{H}$ NMR $\left(500 \mathrm{MHz}, \mathrm{D}_{2} \mathrm{O}\right) \delta 6.76(\mathrm{~s}, 1 \mathrm{H}), 6.66$ $(\mathrm{d}, 1 \mathrm{H}, J=8.0), 6.59$ (d, $1 \mathrm{H}, J=8.0 \mathrm{~Hz}), 3.68$ (s, 3 $\mathrm{H}), 3.38(\mathrm{~s}, 2 \mathrm{H}) ;{ }^{13} \mathrm{C}$ NMR $\left(100 \mathrm{MHz}, \mathrm{D}_{2} \mathrm{O}\right) \delta 171.7$, $165.2,147.3,142.7,134.4,120.5,115.5,112.4,94.9$, 56.0, 27.2. 5-(4-Hydroxy-3,5-dimethoxybenzyl)-2thioxodihydropyrimidine-4,6 $(1 H, 5 H)$-dione (compound 21): ${ }^{1} \mathrm{H}$ NMR (400 MHz, $\left.\mathrm{D}_{2} \mathrm{O}\right) 6.44(\mathrm{~s}, 2 \mathrm{H}), 3.66$ (s, $6 \mathrm{H}), 3.37$ (s, $2 \mathrm{H}) ;{ }^{13} \mathrm{C}$ NMR $\left(100 \mathrm{MHz}, \mathrm{D}_{2} \mathrm{O}\right) 171.8$, $165.2,147.7,133.8,131.8,105.4,94.7,56.4,27.7$. This chemical was dissolved in dimethylsulfoxide (DMSO). Lipopolysaccharide (LPS) (from Escherichia coli 0111: B4, CAS registry no. L2630) and other chemical reagents were purchased from Sigma (St. Louis, MO, USA).

\section{Animal experiments}

All animal experiments were approved by the Pusan National University-Institutional Animal Care and Use Committee (PNU-IACUC). C57/BL6 male mice (weight 30-32 g, 6 weeks of age) were purchased from Japan SLC (Hamamatsu, Japan). This study followed the Guide for Animal Care and Use issued by the Institute of Laboratory Animal Resources (ISBN 0-309-05377-3). Fifty C57/BL6 mice were assigned to one of the following six groups: 1) a saline injected group (the control group, $n=5$ ); 2) a $5 \mathrm{mg} / \mathrm{kg}$ LPS group (the LPS group, $n=5$ ); 3-4) two compound 2d (at 1or $5 \mu \mathrm{M}$ ) plus $5 \mathrm{mg} / \mathrm{kg}$ LPS groups (compound $2 \mathrm{~d}+\mathrm{LPS}$ groups, $n=5$ ); and 5-6) two compound 21 (at 1 or $5 \mu \mathrm{M}$ ) plus $5 \mathrm{mg} / \mathrm{kg}$ LPS groups (compound 21+LPS groups, $n=5$ ). Saline, compound $2 \mathrm{~d}$, and compound 21 were administered $2 \mathrm{~h}$ prior to LPS (or saline for the control group) treatment. Mice were dissected $2 \mathrm{~h}$ after LPS treatment.

\section{Tissue homogenate}

All solutions and materials were maintained at $0 \sim 4^{\circ} \mathrm{C}$. Liver samples were homogenized in $1 \mathrm{ml}$ of homogenate buffer $\mathrm{A}\left[10 \mathrm{mM} \mathrm{KCl}, 2 \mathrm{mM} \mathrm{MgCl}_{2}, 1\right.$ $\mathrm{mM}$ dithiothreitol (DTT), $0.1 \mathrm{mM}$ EDTA, $0.1 \mathrm{mM}$ phenylmethanesulfonyl fluoride (PMSF), $1 \mu \mathrm{M}$ pepstatin, $2 \mu \mathrm{M}$ leupeptin, $20 \mathrm{mM} \beta$-glycerophosphate, $20 \mathrm{mM}$ $\mathrm{NaF}, 2 \mathrm{mM} \mathrm{Na} \mathrm{VO}_{4}$, and $10 \mathrm{mM}$ 4-(2-hydroxyethyl)-1piperazineethanesulfonic acid (HEPES), pH7.4] with a tissue homogenizer for $20 \mathrm{~s}$ and put on ice for $15 \mathrm{~min}$. Then, $125 \mu \mathrm{l}$ of $10 \%$ Nonidet P-40 (NP-40) was added and mixed on ice for $15 \mathrm{~s}$, and the homogenate was centrifuged at $14,000 \mathrm{~g}$ at $4{ }^{\circ} \mathrm{C}$ for $2 \mathrm{~min}$. The supernatants were used as the cytosolic sample. The pellets were resuspended in homogenate buffer C [ $50 \mathrm{mM} \mathrm{KCl}, 300 \mathrm{mM} \mathrm{NaCl}, 0.1$ mM PMSF, 10\% (v/v) glycerol, $1 \mu \mathrm{M}$ pepstatin, $2 \mu \mathrm{M}$ leupeptin, $20 \mathrm{mM} \beta$-glycerophosphate, $20 \mathrm{mM} \mathrm{NaF}, 2 \mathrm{mM}$ $\mathrm{Na}_{3} \mathrm{VO}_{4}$, and $50 \mathrm{mM}$ HEPES,pH 7.8], kept on ice for 30 min, and centrifuged at $14,000 \mathrm{~g}$ at $4^{\circ} \mathrm{C}$ for $10 \mathrm{~min}$. Each sample was stored at $-80{ }^{\circ} \mathrm{C}$ in a deep freezer. Protein concentration was determined using the bicinchoninic acid (BCA) assay using bovine serum albumin (BSA) as a standard.

\section{Cell culture}

RAW264.7 cells (a murine macrophage cell line) were purchased from the American Type Culture Collection (ATCC, Manassas, VA, USA). Cells were used at $37^{\circ} \mathrm{C}$ in Dulbecco's Modified Eagle's Medium (DMEM; Hyclone Laboratories, Logan, Utah, USA) containing 2 $\mathrm{mM}$ L-glutamine, 100 units $/ \mathrm{ml}$ penicillin, $100 \mu \mathrm{g} / \mathrm{ml}$ streptomycin, and $10 \%$ heat-inactivated fetal bovine serum (FBS, Hyclone). Cells were incubated at $37^{\circ} \mathrm{C}$ in 5 $\% \mathrm{CO}_{2} / 95 \%$ air atmosphere.

\section{Cell lysis}

The cell was harvested at $3,000 \mathrm{rpm}$ at $4{ }^{\circ} \mathrm{C}$ for 5 $\mathrm{min}$. The pellets were suspended in lysis buffer containing $10 \mathrm{mM}$ Tris, $\mathrm{pH} 8.0,1.5 \mathrm{mM} \mathrm{MgCl}, 1 \mathrm{mM}$ DTT, 0.1\%NP$40,1 \mu \mathrm{M}$ pepstatin, and $1 \mathrm{mM} p$-aminobenzamidine on ice for $15 \mathrm{~min}$ and then centrifuged at $13,000 \mathrm{~g}$ at $4{ }^{\circ} \mathrm{C}$ for 15 $\mathrm{min}$. The supernatants were used as the cytosolic sample. The pellets were resuspended using nucleus lysis buffer containing $10 \mathrm{mM}$ Tris-pH 8.0, $50 \mathrm{mM} \mathrm{KCl}, 100 \mathrm{mM}$ $\mathrm{NaCl}, 1 \mu \mathrm{M}$ pepstatin, and $1 \mathrm{mM} p$-aminobenzamidine, placed on ice for $30 \mathrm{~min}$, and then centrifuged at $14,000 \mathrm{~g}$ at $4^{\circ} \mathrm{C}$ for $30 \mathrm{~min}$. The resultant supernatants were used as the nuclear sample. Protein concentration was determined by the BCA assay using BSA as a standard.

\section{Cell viability assay}

Briefly, RAW264.7 cells were seeded at $1.5 \times 10^{4}$ cells per/well in 96-well plates and then incubated at 
$37^{\circ} \mathrm{C}$ for $24 \mathrm{~h}$ and treated with samples. Cell viability was measured by the EZ-cy tox cell viability Assay kit (Daeil Lab Service, Seoul, Korea) as previously described.

\section{Western blot}

Western blotting was performed as previously described [25]. Primary antibodies were as follows: pP65 (Ser 536) (sc3020), pP65 (Ser 276) (sc101749), P65 (sc372), COX-2 (cyclooxygenase 2) (sc1747-R), inducible nitric oxide synthase (iNOS) (sc7271), AKT (sc1618), pAKT (Ser 473) (sc7985), inhibitor of kappa B alpha (IKB $\alpha)$ (sc847), pIKB $\alpha$ (Ser32) (sc8404), inhibitor of kappa B kinase alpha/ beta $(\mathrm{IKK} \alpha / \beta)$ (sc7607), $\beta$-Actin (sc47778), and transcription factor IIB (TFIIB) (sc225) were purchased from Santa Cruz Biotechnology (Dallas, TX, USA). pIKK $\alpha / \beta$ (Ser 176/180) (\#2697s) and PTEN and phosphoinositide dependent kinase 1 (PDK1) Ab sample kit (\#9652) were purchased from Cell Signaling (Beverly, MA, USA).

\section{Quantitation of redox status}

To evaluate redox status-scavenging activity, RAW264.7 cells were seeded at $1 \times 10^{4}$ cells/well in a black 96-well plate and incubated overnight with SIN1 and LPS to induce the generation of reactive oxygen species (ROS). Trolox was used as a positive control as an ROS scavenger, and penicillamine was used as a positive control as a peroxynitrite (ONOO-) scavenger.

\section{ROS measurement}

ROS generation was measured using a fluorescence probe, as previously described. Briefly, $50 \mu \mathrm{M} 2^{\prime}, 7^{\prime}$-dic hlorodihydrofluorescein diacetate (DCFDA) was added to homogenates for a final volume of $250 \mu \mathrm{l}$. Changes in fluorescence were detected with a GENios plate reader (Tecan Instruments, Salzbrug, Austria) with excitation and emission wavelengths set at 485 and $530 \mathrm{~nm}$, respectively. In addition, changes in ROS level were detected using a laser-scanning confocal microscope on RAW264.7 cells seeded at $2 \times 10^{5}$ cells/well in a 6 -well cell culture dish.

\section{ONOO- measurement $^{-}$}

$\mathrm{ONOO}^{-}$generation was examined by measuring the oxidation of dihydrorhodamine (DHR123). Briefly, liver homogenate $(10 \mu \mathrm{l})$ was mixed with the rhodamine solution $(50 \mathrm{mM}$ sodium phosphate buffer, $90 \mathrm{mM} \mathrm{NaCl}$, $5 \mathrm{mM}$ diethylene-triamine pentaacetate [DTPA], and DHR 123) to a final volume of $200 \mu \mathrm{l}$. Changes in fluorescence intensity were measured every 5 min for 30 min using a fluorescence plate reader at excitation and emission wavelengths of 485 and $530 \mathrm{~nm}$, respectively. In addition, the fluorescence of $\mathrm{ONOO}^{-}$generated in the cytoplasm of RAW264.7 ( 2 X $10^{5}$ cells/well) was directly confirmed using a laser-scanning confocal microscope.

\section{Immunostaining}

RAW264.7 cells were seeded at $3 \times 10^{4}$ cells per well in a 12-well plate and incubated overnight. Cells were fixed in $4 \%$ paraformaldehyde solution for $30 \mathrm{~min}$, washed with phosphate buffered saline (PBS), blocked with $3 \%$ normal goat serum (Gibco, Grand Island, NY, USA), and immunostained with rabbit anti-nuclear

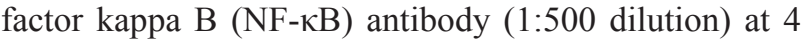
${ }^{\circ} \mathrm{C}$ overnight. Cells were then washed with Tris-buffered saline (TBS) and incubated for $2 \mathrm{~h}$ with anti-rabbit $\operatorname{IgG}$ labeled with Alexa Fluor 488 (1:200 dilutions, Invitrogen, Carlsbad, CA, USA). Immunostaining was performed using Hoechst 33342 (1:1,000 dilution, Invitrogen) to visualize the cells, and NF- $\mathrm{KB}$ location was determined using confocal laser scanning microscopy (TCS SP2, Leica, Wetzlar, Germany).

\section{Luciferase assay}

For luciferase assays, $1 \mu \mathrm{g}$ of plasmid was transfected into RAW264.7 cells $\left(5 \times 10^{4}\right.$ cells per well) seeded in a 24 -well plate in $500 \mu \mathrm{L}$ of DMEM supplemented with $10 \% \mathrm{FBS}$ at $37^{\circ} \mathrm{C}$ in a humidified 95 $\%$ air $/ 5 \% \mathrm{CO}_{2}$ atmosphere. Cells were transfected with Lipofectamine transfection reagent, and the plasmids used for transfection contained the NF- $\mathrm{kB}$ - luciferase reporter vector. After $12 \mathrm{~h}$ of transfection, cells were washed and treated with compounds $2 \mathrm{~d}$ and $2 \mathrm{l}$ for $6 \mathrm{~h}$. Luciferase activity was detected using the One-Glo luciferase assay system (Promega, Madison, WI, USA) and measured using a Tecan GENios luminescence plate reader.

\section{Statistical analysis}

All results are expressed as means \pm standard error of the means (SEM). One-way analysis of variance (ANOVA) was performed to analyze significant differences among all groups. Dunnett's test was used to determine the significance between group means. An associated probability ( $p$-value) of $<0.05$ was considered statistically significant.

\section{ACKNOWLEDGMENTS AND FUNDING}

This work was supported by the National Research Foundation of Korea (NRF) grant funded by the Korea government (MSIP) (No. 2009-0083538). This work was also supported by Grant K17281 from the Korea Institute of Oriental Medicine, Ministry of Education, Science and Technology (MEST), Republic of Korea. We also thank the Korea Aging Tissue Bank for providing research materials.

\section{CONFLICTS OF INTEREST}

The authors have no conflicts of interest to disclose. 


\section{REFERENCES}

1. Shi C, Pamer EG. Monocyte recruitment during infection and inflammation. Nat Rev Immunol. 2011; 11: 762-74. https://doi.org/10.1038/nri3070.

2. Parsons CJ, Takashima M, Rippe RA. Molecular mechanisms of hepatic fibrogenesis. J Gastroenterol Hepatol. 2007; 22: S79-84. https://doi.org/10.1111/j.1440-1746.2006.04659.x.

3. Friedman SL. Mechanisms of disease: Mechanisms of hepatic fibrosis and therapeutic implications. Nat Clin Pract Gastroenterol Hepatol. 2004; 1: 98-105. https://doi. org/10.1038/ncpgasthep0055.

4. Brenner DA. Molecular pathogenesis of liver fibrosis. Trans Am Clin Climatol Assoc. 2009; 120: 361-8.

5. Klein I, Cornejo JC, Polakos NK, John B, Wuensch SA, Topham DJ, Pierce RH, Crispe IN. Kupffer cell heterogeneity: functional properties of bone marrow derived and sessile hepatic macrophages. Blood. 2007; 110: 407785. https://doi.org/10.1182/blood-2007-02-073841.

6. Martinez FO, Gordon S. The M1 and M2 paradigm of macrophage activation: time for reassessment. F1000Prime Rep. 2014; 6: 13. https://doi.org/10.12703/P6-13.

7. Mosser DM, Edwards JP. Exploring the full spectrum of macrophage activation. Nat Rev Immunol. 2008; 8: 958-69. https://doi.org/10.1038/nri2448.

8. Kiemer AK, Muller C, Vollmar AM. Inhibition of LPSinduced nitric oxide and TNF-alpha production by alphalipoic acid in rat Kupffer cells and in RAW 264.7 murine macrophages. Immunol Cell Biol. 2002; 80: 550-7. https:// doi.org/10.1046/j.1440-1711.2002.01124.x.

9. Jiang BH, Liu LZ. PI3K/PTEN signaling in angiogenesis and tumorigenesis. Adv Cancer Res. 2009; 102: 19-65. https://doi.org/10.1016/S0065-230X(09)02002-8.

10. Cantley LC, Neel BG. New insights into tumor suppression: PTEN suppresses tumor formation by restraining the phosphoinositide 3-kinase/AKT pathway. Proc Natl Acad Sci U S A. 1999; 96: 4240-5.

11. Gupta SC, Hevia D, Patchva S, Park B, Koh W, Aggarwal BB. Upsides and downsides of reactive oxygen species for cancer: the roles of reactive oxygen species in tumorigenesis, prevention, and therapy. Antioxid Redox Signal. 2012; 16: 1295-322. https://doi.org/10.1089/ars.2011.4414.

12. Leslie NR, Bennett D, Lindsay YE, Stewart H, Gray A, Downes CP. Redox regulation of PI 3-kinase signalling via inactivation of PTEN. EMBO J. 2003; 22: 5501-10. https:// doi.org/10.1093/emboj/cdg513.

13. Oeckinghaus A, Ghosh S. The NF-kappaB family of transcription factors and its regulation. Cold Spring Harb Perspect Biol. 2009; 1: a000034. https://doi.org/10.1101/ cshperspect.a000034.

14. Sasaki K, Iwai K. Roles of linear ubiquitinylation, a crucial regulator of NF-kappaB and cell death, in the immune system. Immunol Rev. 2015; 266: 175-89. https://doi. org/10.1111/imr.12308.
15. Kim JH, Lee G, Cho YL, Kim CK, Han S, Lee H, Choi JS, Choe J, Won MH, Kwon YG, Ha KS, Kim YM. Desmethylanhydroicaritin inhibits NF-kappaB-regulated inflammatory gene expression by modulating the redoxsensitive PI3K/PTEN/Akt pathway. Eur J Pharmacol. 2009; 602: 422-31. https://doi.org/10.1016/j.ejphar.2008.10.062.

16. Ma XF, Zhang J, Shuai HL, Guan BZ, Luo X, Yan RL. IKKbeta/NF-kappaB mediated the low doses of bisphenol A induced migration of cervical cancer cells. Arch Biochem Biophys. 2015; 573: 52-8. https://doi.org/10.1016/j. abb.2015.03.010.

17. Brasier AR. The nuclear factor-kappaB-interleukin-6 signalling pathway mediating vascular inflammation. Cardiovasc Res. 2010; 86: 211-8. https://doi.org/10.1093/cvr/cvq076.

18. Liaskou E, Wilson DV, Oo YH. Innate immune cells in liver inflammation. Mediators Inflamm. 2012; 2012: 949157. https://doi.org/10.1155/2012/949157.

19. Pradere JP, Kluwe J, De Minicis S, Jiao JJ, Gwak GY, Dapito DH, Jang MK, Guenther ND, Mederacke I, Friedman R, Dragomir AC, Aloman C, Schwabe RF. Hepatic macrophages but not dendritic cells contribute to liver fibrosis by promoting the survival of activated hepatic stellate cells in mice. Hepatology. 2013; 58: 1461-73. https://doi.org/10.1002/hep.26429.

20. Possamai LA, Antoniades CG, Anstee QM, Quaglia A, Vergani D, Thursz M, Wendon J. Role of monocytes and macrophages in experimental and human acute liver failure. World J Gastroenterol. 2010; 16: 1811-9.

21. Ito K, Zolfaghari R, Hao L, Ross AC. Inflammation rapidly modulates the expression of ALDH1A1 (RALDH1) and vimentin in the liver and hepatic macrophages of rats in vivo. Nutr Metab (Lond). 2014; 11: 54. https://doi. org/10.1186/1743-7075-11-54.

22. Kirkham P. Oxidative stress and macrophage function: a failure to resolve the inflammatory response. Biochem Soc Trans. 2007; 35: 284-7. https://doi.org/10.1042/ BST0350284.

23. Lee SR, Yang KS, Kwon J, Lee C, Jeong W, Rhee SG. Reversible inactivation of the tumor suppressor PTEN by $\mathrm{H}_{2} \mathrm{O}_{2}$. J Biol Chem. 2002; 277: 20336-42. https://doi. org/10.1074/jbc.M111899200.

24. Robinson MW, Harmon C, O'Farrelly C. Liver immunology and its role in inflammation and homeostasis. Cell Mol Immunol. 2016; 13: 267-76. https://doi.org/10.1038/cmi.2016.3.

25. Lee B, Moon KM, Son S, Yun HY, Han YK, Ha YM, Kim DH, Chung KW, Lee EK, An HJ, Ullah S, Chun P, Moon HR, et al. (2R/S,4R)-2-(2,4-Dihydroxyphenyl)thiazolidine4-carboxylic acid prevents UV-induced wrinkle formation through inhibiting NF-kappaB-mediated inflammation. J Dermatol Sci. 2015; 79: 313-6. https://doi.org/10.1016/j. jdermsci.2015.06.013. 